\title{
POTRET PEREMPUAN DALAM NOVEL TARIAN BUMI KARYA OKA RUSMINI
}

\author{
(Sebuah Tinjauan Feminisme Sastra)
}

\author{
Andi Sutisno \\ Universitas Swadaya Gunung Jati Cirebon \\ aksaraabdikata@gmail.com
}

\begin{abstract}
ABSTRAK
Karya sastra merupakan pengejawantahan kehidupan. Dalam konteks tersebut, karya sastra dibuat untuk menggambarkan realitas hidup masyarakat, salah satunya adalah kehidupan perempuan. Persoalan-persoalan yang berkaitan dengan kehidupan perempuan selalu menarik untuk diangkat ke dalam cerita karya sastra. Tentu saja hal ini memberikan pembelajaran kepada masyarakat tentang posisi dan peran perempuan itu sendiri dalam kehidupan, baik sebagai individu maupun kelompok masyarakat. Gerakan feminis memberikan ruang lain dalam khazanah apresiasi dan kritik sastra. Kritik sastra feminis hadir seiring dengan massifnya gerakan feminisme itu sendiri. Kajian sastra dengan pendekatan feminisme ini membuka ruang-ruang interpretasi atas perempuan dalam karya sastra. Novel sebagai salah satu karya sastra yang berisikan peristiwa-peristiwa dan konflik-konflik yang kompleks, tentunya memberikan keluasan interpretasi juga, termasuk di dalamnya menginterpretasikan tokoh perempuan dan posisinya dalam novel tersebut.
\end{abstract}

Kata kunci: karya sastra, novel, kritik sastra feminis

\section{A. PENDAHULUAN}

Karya sastra merupakan gambaran kehidupan yang selalu memberikan nilainilai kepada masyarakat. Dengan karya sastra, seseorang dapat mengambil banyak hal terkait dengan hidup dan kehidupan. Dengan kata lain, karya sastra tidak hanya memberikan kenikmatan dan kepuasan batin, tetapi juga sebagai sarana penyampaian pesan moral kepada masyarakat atas realitas sosial.

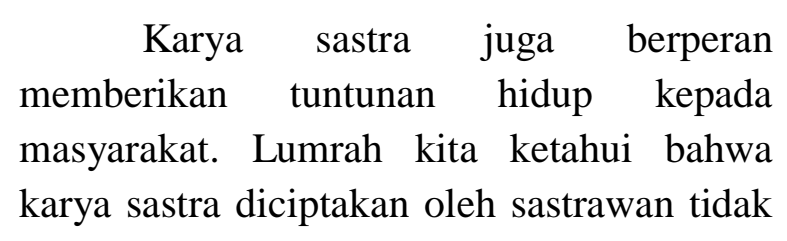

semata-mata hasil dari imajinasi tetapi juga kontemplasi yang mendalam agar apa yang ditulis dapat dijadikan pelajaran hidup yang berharga. Dalam prosesnya, karya sastra yang dibuat oleh sastrawan tidak hanya membahas nilai sosial dan budaya, tetapi juga membahas perjuangan seorang tokoh, baik tokoh perempuan maupun laki-laki. Peran tokoh perempuan dalam sebuah karya sastra memiliki kontribusi besar, tidak jarang peran tokoh perempuan ini dideskripsikan oleh penulis laki-laki. Dalam konteks tersebut, kajian feminisme sastra berperan sebagai sebuah pisau analisis untuk 


\section{DEIKSIS - JURNAL PENDIDIKAN BAHASA DAN SASTRA INDONESIA}

memberikan gambaran tentang kekuatankekuatan kaum perempuan.

Perempuan adalah sosok yang mempunyai dua sisi. Di satu pihak, perempuan adalah keindahan, pesonanya dapat membuat laki-laki tergila-gila (Sugihastuti, 2010: 32). Di sisi yang lain, ia dianggap lemah. Anehnya, kelemahan itu dijadikan alasan laki-laki jahat untuk mengeksploitasi keindahannya. Bahkan, ada juga yang beranggapan perempuan itu hina, manusia kelas dua yang walaupun cantik, tidak diakui eksistensinya sebagai manusia sewajarnya.

Novel sebagai salah satu karya sastra merupakan sarana atau media yang menggambarkan apa yang ada di dalam pikiran sastrawan. Pada saat sastrawan memunculkan tokoh perempuan dalam karyanya, data-data atau informasi yang ia kemukakan bisa berasal dari orang lain maupun dari pengalamannya sendiri. Dalam sebuah novel, banyak ditemukan tokoh perempuan. Dalam persepektif feminisme tentu saja ini adalah bahan kajian menarik yang dapat ditelaah oleh para kritikus sastra. Peran perempuan dalam karya sastra bisa ditarik ke dalam peran dan posisi perempuan dalam konteks masyarakat itu sendiri. Hal ini pula yang mendasari penulis untuk menganalisis potret perempuan dalam novel Tarian Bumi karya Oka Rusmini. Pada novel ini banyak melibatkan tokoh perempuan dengan berbagai kompleksitas hidup yang dihadapinya.

\section{B. KAJIAN TEORETIS}

Feminisme dalam sastra berhubungan dengan studi sastra yang mengarahkan fokus analisis kepada perempuan (Sugihastuti, 2010: 27). Dalam konteks tersebut, karya sastra melibatkan perempuan sabagai bahan kajiannya. Bahan kajian di sini tentu saja tidak pada sebatas tokoh perempuan semata tetapi lebih jauh pada bagaimana juga penggambaran tokoh perempuan dilihat dari perspektif tokoh lain. Selain itu, sastrawan juga berpengaruh terhadap pemosisian tokoh perempuan yang dimunculkan dalam karyanya.

Feminisme tentu saja berbeda dengan emansipasi. Sofia (Sugihastuti, 2007: 95) menjelaskan bahwa emansipasi lebih berfokus pada keikutsertaan dalam pembangunan dengan tidak mempermasalahkan hak serta kepentingan mereka yang dinilai tidak adil. Sedangkan feminisme memandang perempuan memiliki aktivitas dan inisiatif sendiri untuk memperebutkan hak dan kepentingan tersebut dalam berbagai gerakan. Dengan kata lain, feminisme merupakan gerakan aktif yang melibatkan segala akal dan perbuatan perempuan dalam aktivitasnya di tengah-tengah masyarakat.

Sholwalter (Sugihastuti dan Suharto, 2010: 210) menyatakan bahwa dalam ilmu sastra, feminisme ini berhubungan dengan konsep kritik sastra feminis, yaitu studi sastra yang memfokuskan studi analisisnya pada perempuan. Dalam konteks ini, studi sastra feminis menitikberatkan pada pemikiran dan perbuatan perempuan dalam karya sastra yang kemudian dikomparasikan dengan realitas kehidupan perempuan dalam kehidupan bermasyarakat. Dengan kata lain, studi sastra feminis ingin mendeskripsikan 


\section{DEIKSIS - JURNAL PENDIDIKAN BAHASA DAN SASTRA INDONESIA}

potret perempuan dalam kehidupan dan karya sastra.

Feminisme bukan upaya pemberontakan terhadap laki-laki, bukan upaya melawan pranata sosial, budaya seperti perkawinan, rumah tangga, maupun bidang publik. Kaum perempuan pada intinya tidak mau dimarjinalkan. Menurut Hannam (Ansori, 2007: 22) dalam pandangan feminisme peran perempuan memiliki kedudukan yang sama dengan lakilaki. Feminisme sendiri muncul karena hakhak kaum perempuan sering dikesampingkan dalam beberapa aspek. Perempuan seringkali diposisikan sebagai kaum kelas kedua yang selalu dilabeli kelemahan. Padahal, perempuan memiliki otonomi hak yang tentu saja hak-hak tersebut sederajat dengan kaum laki-laki. Misal, hak dalam pendidikan, pekerjaan, dan pengelolaan rumah tangga.

\section{METODOLOGI}

Metode yang digunakan dalam penelitian ini adalah metode deskriptif analitik. Sukmadinata (2012: 72) menjelaskan bahwa penelitian deskriptif ditunjukan untuk mendeskripsikan gejalagejala yang ada, baik gejala yang bersifat alamiah atau rekayasa manusia. Adapun pengertian pendekatan deskriptif. Menurut Arikunto (2010: 3) bahwa penelitian deskriptif adalah penelitian yang dimaksudkan untuk menyelidiki keadaan, kondisi atau hal lain-lain yang hasilnya dipaparkan dalam bentuk penelitian. Laporan hasil penelitian ini berupa kutipankutipan dari kumpulan data dengan bahasa verbal yang cermat sangat dipentingkan karena semua interpretasi dan kesimpulan yang diambil disimpulkan secara verbal.

\section{PEMBAHASAN}

\section{Peran Ida Ayu Telaga sebagai Anak}

Peran anak sejatinya adalah berbakti kepada orang tua. Salah satu perwujudan bakti anak kepada orang tua dapat berupa kepatuhan dan membantu orang tuanya. Namun kepatuhan anak kepada orang tuanya tersebut tidak bersifat mutlak. Dengan kata lain, kepatuhan tersebut akan berlaku manakala hal tersebut tidak bertentangan dengan hati nurani si anak, namun jika berseberangan dengan hati nurani si anak, nilai-nilai kepatuhan tersebut tidak berlaku.

Ida Ayu Telaga adalah perempuan bangsawan yang terlahir dari kasta Brahmana. Kasta Brahmana merupakan kasta tertinggi dalam sistem kasta di Bali. Ia adalah harapan bagi ibunya karena kelak ia harus menikah dengan laki-laki yang memiliki nama depan Ida Bagus. Dalam kehidupan tata adat di Bali kaum bangsawan harus menikah lagi dengan kaum bangsawan. Sehingga, pada saat Ida Ayu Telaga menginjak usia menikah, maka lakilaki yang bernama Ida Baguslah yang harus menjadi suaminya. Hal tersebut tampak pada kutipan novel Tarian Bumi, 2007: 68.

Bagi masyarakat Bali, gelar kebangswanan merupakan hal yang sangat dijunjung tinggi. Hal tersebut tidak berlaku bagi Ida Ayu Telaga. Ia menganggap bahwa gelar kebangswanannya hanya kulit luar yang melekat pada dirinya saja, tetapi hakikat diri sebagai manusia bagi Ida Ayu Telaga sama saja. Dengan kata lain, menurutnya, semua manusia pada 


\section{DEIKSIS - JURNAL PENDIDIKAN BAHASA DAN SASTRA INDONESIA}

hakikatnya memiliki derajat yang sama. Ia menganggap bahwa manusia di dunia memiliki peran dan posisi yang sama dalam masyarakat. Selain itu, Ida Ayu Telaga tidak ingin hidupnya sengsara hanya karena terlalu banyak aturan kebangsawanan yang harus dipatuhinya. Ida Ayu Telaga ingin hidup bahagia seperti yang diinginkannya, walaupun ia harus berkorban dengan meninggalkan darah bangsawannya akibat pernikahannya dengan Wayan Samitha yang berasal dari kasta Sudra, kasta terendah dalam budaya Bali. Ida Ayu Telaga pun harus meninggalkan nama Ida Ayu dan menyandang Luh di depan namanya dan melakukan upacara patiwangi untuk menanggalkan kebangsawanannya. Hal tersebut tampak pada kutipan novel Tarian Bumi, 2007: 175.

Meskipun Ida Ayu Telaga beranjak dari kasta Brahmana, ia tidak pernah marasa lebih tinggi dari kasta-kasta lainnya, termasuk kasta Sudra. Hal tersebut terbukti dengan garis hidup yang dipilihnya yakni dengan menikahi laki-laki yang berasal dari kasta Sudra yang bernama Wayan Sasmitha.

\section{Peran Ida Ayu Telaga di Masyarakat}

Dalam kehidupan bermasyarakat, seseorang memiliki pilihan yang berbeda dengan yang lainnya. Masing-masing individu memiliki pilihannya. Hal ini juga yang terjadi pada Ida Ayu Telaga. Pilihan hidup Ida Ayu Telaga berbeda dengan ibunya yang menjunjung tingg dan adat kebangsawanan di Bali. Menurut Telaga, kedudukan tinggi kasta Brahmana tidak serta merta menjadikan orang-orang yang ada di dalamnya juga memiliki budi pekerti yang luhur. Oleh karena itu, bagi Ida Ayu Telaga tidak ada sekat yang harus dirisaukan untuk ia bergaul di tengah-tengah masyarakat. Hal ini terbukti dengan dirinya yang jatuh cinta kepada Wayan Sasmitha, seorang laki-laki yang berasal dari kasta Sudra. Konsekuensinya adalah Telaga harus melepaskan gelar kebangsawanannya. Artinya, ia harus melepaskan gelar Ida Ayunya. Telaga tinggal bersama keluarga Wayan di sebuah rumah sederhana dengan kehiduan yang sederhana pula. Tapi, Telaga mendapatkan kebahagiaan yang sempurna.

Telaga juga digambarkan sebagai seorang perempuan yang menentang adat yang berlaku di Bali. Telaga pun akhirnya dibuang oleh keluarganya dan tidak dianggap lagi sebagai perempuan Brahmana karena menikah dengan laki-laki dari kasta Sudra. Kutipan berikut menggambarkan saat ibunya menanggalkan kastanya sebagai perempuan Barahmana.

hari ini juga tiang akan menanggalkan nama Ida Ayu. Tiang akan jadi perempuan Sudrayang utuh... (Tarian Bumi, $2007: 173$ ).

Telaga telah memberikan gambaran kepada kita bahwa perempuan juga patut memperjuangkan haknya. Dalam konteks tersebut, menentukan pilihan hidup adalah hak bagi setiap orang, tidak mengenal jenis kelamin juga kasta dalam masyarakat. Dengan kata lain, Telaga memberikan gambaran kepada masyarakat luas terkait dengan eksistensi manusia dalam kehidupannya. 


\section{DEIKSIS - JURNAL PENDIDIKAN BAHASA DAN SASTRA INDONESIA}

\section{Peran Luh Sekar sebagai Ibu}

Ibu sejatinya memberi rasa aman dan perlindungan kepada anak-anaknya walaupun dengan cara dan kemampuan yang berbeda. Dalam hal ini Luh Sekar dengan kekurangan dan kelemahannya, ia tetap berusaha memberikan yang terbaik kepada anaknya dengan caranya sendiri. Sekar yang berasal dari kasta Sudra berusaha menikah dengan kasta Brahmana demi kebahagiaan anak-anaknya kelak. Hal ini digambarkan pada kutipan berikut.

$\mathrm{Aku}$ capek miskin, Kenten. Kau harus tau itu. Tolonglah, carikan aku seorang Ida Bagus. Apa pun yang harus kubayar, aku siap! (Tarian Bumi, 2007 : 17).

Semangat Luh Sekar menjadi kenyataan ketika dia menikah dengan lelaki berdarah biru, Ida Bagus Ngurah Pidada. Dengan pernikahan itu, selamanya Luh Sekar tidak pernah tahu bahwa sahabatnya Luh Kenten menaruh hati kepadanya. Sayangnya pernikahan Luh Sekar tidaklah bahagia. Suaminya yang bangsawan ternyata lelaki pemabuk dan bercinta dengan sembarang perempuan, termasuk adik tiri Luh Sekar. Luh sekar membayar mahal untuk menukar kenyamanan hidupnya dengan memasuki dunia bangsawan. Mertuanya keji dan selalu memandang rendah padanya. Suaminya berkhianat berkali-kali dan tidak berguna. Berdasarkan gambaran tersebut, menunjukan bahwa gelar kebangsawanan tidak menjadi jaminan akan kenyamanan hidup seseorang.

\section{Peran Luh Sekar sebagai Isteri}

Luh Sekar seorang Sudra yang memiliki ambisi yang sangat besar terhadap kebangsawanan. Ia sangat tidak menginginkan menjadi seorang Sudra yang miskin. Oleh karena itu, demi menggapai impiannya itu, ia rela menikah dengan seorang Ida Bagus Ngurah Pidada, seorang keturunan Brahmana dengan perilaku yang buruk. Konsekuensi pilihan yang hidup yang harus dihadapi bahwa gelar kebangswanan bukanlah jaminan kebahagiaan hidup.

Meskipun ia mempunyai watak yang keras dan ambisi yang sangat besar, namun saat ia menjadi seorang isteri ia tidak bisa berbuat apa-apa. Oleh karena itu, pada saat suaminya berperilaku buruk, ia hanya bisa meratapi nasibnya dan tidak bisa berbuat apa-apa. Bahkan, manakala suaminya berhubungan intim dengan saudaranya sendiri yaitu Kerta dan Kerti, ia tidak bisa berbuat banyak. Dengan kata lain, ia menerima semua yang telah menajdi pilihan hidupnya. Hidup dengan seseorang yang berasal dari kasta Brahmana tapi nilai-nilai perilakunya jauh dari yang diharapkan. Hal tersebut tampak pada kutipan novel Tarian Bumi, 2007: 84.

Perempuan dengan segala kekuatannya, secara naluriah melekat juga kelemahan dirinya manakala dihadapkan pada persoalan bakti isteri kepada suami. Seorang isteri, apapun situasinya harus tetap mengedepankan penghormatan yang tinggi kepada suami sebab di situlah makna hakiki dari rumah tangga itu sendiri. 


\section{E. SIMPULAN}

Peran perempuan yang terkandung dalam novel Tarian Bumi karya Oka Rusmini dikelompokkan dalam empat bentuk sebagai berikut. Pertama, peran Ida Ayu Telaga sebagai anak. Peran anak sejatinya berbakti kepada orang tua. Salah satu perwujudan bakti kepada orang tua adalah patuh kepada orang tua dan membantu orang tuanya. Namun, kepatuhan itu tidak bersifat mutlak tergantung keinginan dan hati nurani si anak itu sendiri. Kedua, peran Ida Ayu Telaga di masyarakat. Telaga ternyata tidak seperti ibunya yang menjunjung nilai kebangsawanan. Menurut Telaga, kasta Brahmana penuh dengan kebohongan dan kemunafikan. Selain itu, menurutnya, manusia memiliki posisi yang sama dalam kehdiupan bermasyarakat. Ketiga, peran Luh Sekar sebagai Ibu. Ibu sejatinya memberi rasa aman dan perlindungan kepada anaknya. Luh Sekar dengan kekurangan dan kelemahannya, ia tetap berusaha memberikan yang terbaik kepada anaknya. Walaupun dengan caranya sendiri. Keempat, peran Luh Sekar sebagai Isteri. Luh Sekar seorang Sudra yang memiliki ambisi yang sangat besar terhadap kebangsawanan. Ia sangat tidak menginginkan menjadi seorang Sudra yang miskin. Oleh karena itu, demi menggapai impiannya itu, ia rela menikah dengan seorang Ida Bagus Ngurah Pidada, seorang keturunan Brahmana dengan perilaku yang buruk. Konsekuensinya adalah ia harus menerima dengan berbagai kompleksitas persoalan hidup yang telah dipilihnya.

\section{F. DAFTAR PUSTAKA}

Aminudin. (2013). Pengantar Apresiasi Karya Sastra. Bandung: Sinar Baru Algensindo.

Depdiknas. (2008). Kamus Besar Bahasa Indonesia: Edisi Keempat. Jakarta: Balai Pustaka.

Endraswara, Suwardi. (2013). Metodologi Penelitian Sastra. Yogyakarta: CAPS.

Miharja, Ratna. (2012). Sastra Indonesia. Jakarta: Laskar Angkasa.

Miyati. (2012). Kajian Sastra Feminisme. Yogyakarta: Gramedia.

Nadaek, Wilson. (2010). Tentang Sastra. Bandung: Sinar Baru Algensindo.

Nurgiantoro, Burhan. (2010). Teori Pengkajian Fiksi. Yogyakarta: Gadjah Mada University.

Nazir. (2011). Metode Penelitian. Bogor: Galia Indonesia.

Rafiek. (2013). Pengkajian Sastra. Bandung: Refika Aditama.

Rahmanto. (1988). Metode Pengajaran Sastra. Yogyakarta: Kanisius.

Ratna, Nyoman Kutha. (2013). Penelitian Sastra.Yogyakarta: Pustaka Pelajar.

Semi, M. Atar. (1993). Metode Penelitian Sastra. Bandung: Angkasa.

Sugiyono. (2013). Metode Penelitian Kuantitatif Kualitatif dan $R \& D$. Bandung: Alfabeta.

Suharto, Sugihastuti. (2005). Kritik Sastra Feminisme: Teori dan Aplikasinya. Yogyakarta: Pusaka Pelajar.

Wellek, Rene dan Austin Warten. (2014). Teori Kesusastraan. Jakarta: Gramedia. 
DEIKSIS - JURNAL PENDIDIKAN BAHASA DAN SASTRA INDONESIA

Wiyatmi. (2012). Kritik Feminis Teori dan Aplikasianya Dalam Sastra Indonesia. Yogyakarta: Ombak. 